Willemot L., Verborgt O. Complex shoulder instability /dislocation. Issue Rehabil. Orthop. Neurophysiol. Sport Promot. 2018;24: 17-28. DOI: 10.19271/IRONS-00075-2018-24

\section{COMPLEX SHOULDER INSTABILITY/ DISLOCATION}

Laurent Willemot ${ }^{1}$

Olivier Verborgt ${ }^{2,3}$

1Department of Orthopedic Surgery and Traumatology, Ghent University, Ghent, Belgium ${ }^{2}$ Department of Orthopaedic Surgery and Traumatology, AZ Monica, Antwerp, Belgium ${ }^{3}$ Faculty of Medicine and Health Sciences, University of Antwerp, Antwerp, Belgium

\section{SUMMARY}

Traumatic shoulder instability can be complicated by the presence of cartilage injury, glenoid and/or humeral bone defects, rotator cuff injuries and nerve lesions. A high index of suspicion is required in the diagnosis of complex shoulder instability. Patients presenting with continued pain and dysfunction two to three weeks after the initial event should be investigated further. Older patients have a higher risk of associated injuries, but presentation in younger patients is frequent and may lead to devastating outcomes when missed. Correct recognition and treatment of the concomitant injuries is imperative in order to adequately stabilize the glenohumeral joint and avoid long-term dysfunction and degenerative changes. Shoulder instability can also be complicated by prior failed stabilization procedures. Failures are mostly caused by renewed traumatic events, misdiagnosis of the initial pathology or technical errors during the surgery. Type of previous surgical treatment and type of failure will influence the subsequent therapeutic strategy. Surgical history needs to be considered along with patient characteristics, anatomical lesions and functional demands. Clear guidelines in the setting of revision stabilization surgery are not available and treatment should be selected after a thorough case-by-case analysis.

\section{ZŁOŻONA NIESTABILNOŚĆ BARKU/ ZWICHNIĘCIE}

Laurent Willemot ${ }^{1}$

Olivier Verborgt ${ }^{2,3}$

'Department of Orthopedic Surgery and Traumatology, Ghent University, Ghent, Belgia ${ }^{2}$ Department of Orthopaedic Surgery and Traumatology, AZ Monica, Antwerp, Belgia ${ }^{3}$ Faculty of Medicine and Health Sciences, University of Antwerp, Antwerp, Belgia

\section{STRESZCZENIE}

Urazowa niestabilność barku może być bardziej złożona w wyniku urazu chrząstki, ubytków kostnych panewki i/lub kości ramiennej, uszkodzenia pierścienia rotatorów i uszkodzeń nerwów. W rozpoznawaniu złożonej niestabilności barku wymagany jest wysoki wskaźnik nieufności. Pacjenci odczuwający ciągły ból i ograniczenie funkcji dwa do trzech tygodni od urazu powinni być dalej diagnozowani. Starsi pacjenci są bardziej narażeni na współwystępujące uszkodzenia, ale ich występowanie u młodszych pacjentów jest częstsze i może prowadzić do druzgocących wyników w przypadku ich nie rozpoznania. Prawidłowe rozpoznanie i leczenie współistniejących urazów jest konieczne w celu odpowiedniej stabilizacji stawu ramiennego i uniknięcia długotrwałej dysfunkcji i zmian zwyrodnieniowych. Niestabilność barku może być również powikłana przez wcześniejsze nieudane leczenie operacyjne. Niepowodzenia terapii są głównie spowodowane ponownym urazem, nieprawidłowym rozpoznaniem lub trudnościami technicznymi podczas operacji. Zabieg operacyjny i dysfunkcja stawu ramiennego będą miały wpływ na wybór metody leczenia. Historia leczenia operacyjnego musi być brana pod uwage wraz z badaniem pacjenta, zmianami anatomicznymi i wymaganiami funkcjonalnymi leczonego. Nie ma jasnych wytycznych w przypadku rewizji niestabilności stawu ramiennego, ale 
Keywords: shoulder instability, associated lesions, bony defects, nerve lesions, cuff tears, revision surgery.

Date received: 26th December 2017 Date accepted: 10th February 2018

\section{Introduction}

The shoulder offers the greatest range of motion of any joint in the human body. Unfortunately, this generous mobility comes at the cost of an increased risk of instability. Static and dynamic mechanisms interact to stabilize the humeral head in the glenoid socket throughout the range of motion. Nevertheless, the application of sufficient external force can disrupt the stabilizers and result in traumatic subluxation or dislocation. An avulsion or tearing of the anterior capsulolabral complex is typically found in traumatic anterior instability. This, socalled "Bankart" lesion may require surgical repair to prevent further instability. Complex shoulder instability differs from this classical lesion due to the presence of cartilaginous or bony defects on the glenoid or humeral side or both.

\section{Aim}

This research report will address glenohumeral instability complicated by cartilaginous or bony defects, associated cuff and nerve lesions or previous stabilization surgery.

\section{Cartilaginous Injury}

Glenoid sided cartilaginous injury in the setting of shoulder instability most often presents as a gleno-labral-articular-disruption or GLAD lesion (Figure 1). In these cases, the labral injury is continuous with an articular cartilage component (Neviaser, 1993). Patients with this type of injury will report persistent pain and/or instability after shoulder leczenie powinno być wybrane po dokładnej analizie każdego przypadku.

Słowa kluczowe: niestabilność barku, urazy towarzyszące, defekty kości, uszkodzenia nerwów, pierścień rotatorów, chirurgia rewizyjna

Data otrzymania: 26 grudnia 2017

Data zaakceptowania: 10 luty 2018

dislocation. The GLAD lesion is best visualized via advanced imaging techniques such as arthro-CT or arthro-MRI. Arthroscopic evaluation and treatment by labroplasty and, if necessary, microfracture has shown good clinical results. However, only limited evidence is available on long-term outcomes and prevention of early degenerative disease (Page, 2008). Similarly, important chondral lesions can be seen on the humeral head, with variable location and size depending on the type of causative trauma (Figure 2). There are no guidelines for the treatment of central humeral-sided chondral lesions after shoulder instability. Treatment options include conservative, debridement, microfracture, autologous cartilage transplantation, osteochondral allograft or metallic resurfacing (DePalma and Gruson, 2012).

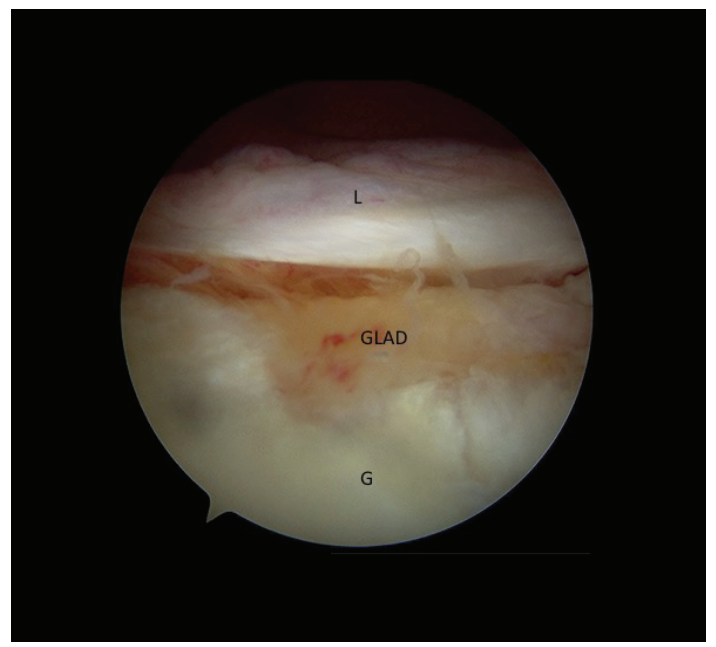

Figure 1. GLAD lesion visualized in a right shoulder in lateral decubitus as seen from the posterior portal. $\mathrm{G}=\mathrm{Gle}$ noid, L=Labrum, GLAD=Gleno-Labral Articular Disruption. 


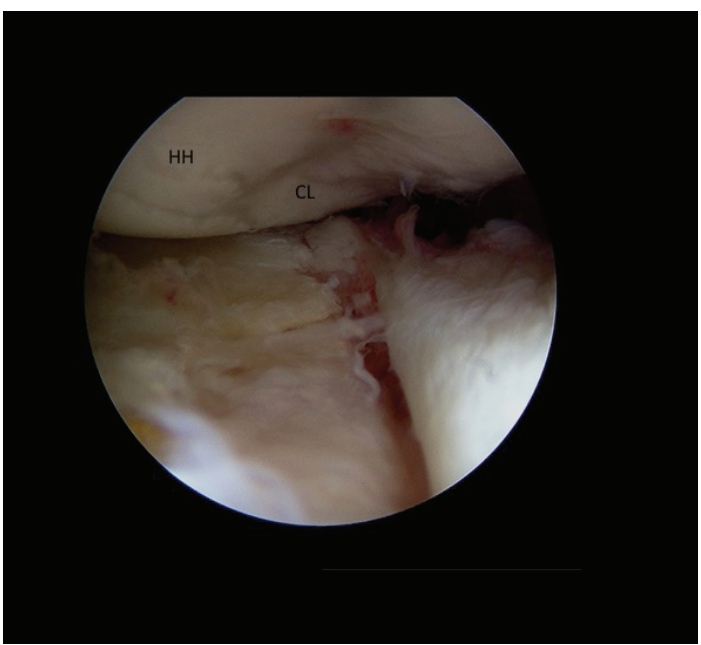

Figure 2. Central chondral lesion on the humeral head of a left shoulder as seen from the superior portal in lateral decubitus. $\mathrm{HH}=$ Humeral Head, $\mathrm{CL}=$ Chondral lesion.

\section{Associated Bone Lesions}

Glenoid bone defects or "bony Bankart lesions", are present in up to $90 \%$ of recurrent dislocations (Taylor et al., 1997). Humeral bone defects or "Hill-Sachs lesions", are seen in up to $100 \%$ of recurrent dislocations (Widjaja et al., 2006). The literature regarding bipolar lesions, with bone loss on the glenoid and humeral side, is limited. Reported incidences vary between $67 \%$ and $87 \%$ (Widjaja et al., 2006; Griffith et al., 2008). Bone loss disrupts the glenohumeral equilibrium between mobility and stability by altering joint's congruency and constraint. A diminished resistance against translational forces and a reduced coverage arc lead to increased soft-tissue stresses, resulting in recurrent instability. Large-scale studies have pointed to the importance of addressing bony lesions in the prevention of chronic instability and the onset of osteo-arthritis (Hovelius et al., 2009).

\section{Glenoid Bone Lesions}

Anterior glenoid defects are subdivided in 'fracture' or 'erosion' type depending on the presence of a bony rim fragment. However, since fragments can resorp within the first year, a distinction between both types isn't always possible. It has been suggested that large fragment defects are caused by high-energy impactions, while smaller bone 'chip' avulsions arise from forced rotational trauma (Burkhart and De Beer, 2000). Glenoid defects are typically found at the 3 o'clock position and oriented parallel to the superior-inferior axis of the glenoid (Figure 3A). Three dimensional computed tomography (3D-CT) reconstruction has become the current imaging technique of choice. In en "en face" view, the defect is measured by comparing the actual glenoid width at the inferior glenoid circle, perpendicular to the supero-inferior axis, to the expected or contralateral inferior glenoid circle diameter (Baudi et al., 2013). Traditionally, 20-25\% bone loss has been the biomechanically relevant threshold (Itoi et al., 2001), yet more recent publications have shown the clinical relevance of smaller amounts of glenoid bone loss (Shaha et al., 2015).

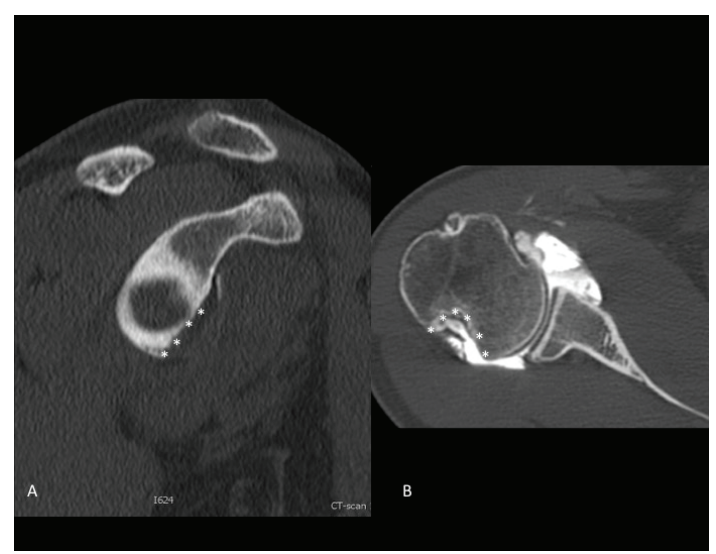

Figure 3. A. Significant anterior glenoid bone loss in the right shoulder of a 25 year old male. B. Significant Hill-Sachs lesion on the humeral head of a 17-year old female. Asterisks indicate lesions.

\section{Humeral Bone Lesions}

Impaction fractures of the posterolateral humeral head caused by impression of the soft cancellous bone on the dense anterior cortical genoid rim are referred to as HillSachs lesions (Figure 3B). It is as yet unclear if these lesions arise during the dislocative trauma or as a secondary injury resulting from muscle pull. A recent study has shown that humeral bone loss is more extensive when time until reduction exceeds 5 hours, 
supporting the latter theory (Denard et al., 2015). Hill-Sachs bone lesions can be described in detail according to their location, depth, orientation, size and volume. Lesions larger than $4 \mathrm{~cm} \times 0.5 \mathrm{~cm}$, with horizontal positioning, covering $20-25 \%$ of articular surface or amounting to $250 \mathrm{~mm}^{3}$ are associated with a higher rate of recurrence (Itoi et al., 2013). This clinical data is support by biomechanical studies showing higher rates of instability with increased humeral bone loss (Kaar et al., 2010). However, recent research has focussed more on the dynamic role of the humeral lesion interacting with the glenoid rim and causing further instability, and less on the static properties of the bony defect.

\section{Bipolar Bone Lesions}

Burkhart and De Beer first reported on the distinction between engaging and non-engaging humeral lesions (Burkart and De Beer, 2000). The authors found that HillSachs lesions that ran parallel to the glenoid rim in abduction-external rotation presented a high risk of "engaging" the glenoid and resulting in instability. The authors advocated peroperative testing of joint stability after Bankart repair to ascertain if the Hill-Sachs lesion would engage. However, there are several difficulties pertinent to this strategy. First, such a manoeuvre seriously risks injuring the freshly repaired labrum and capsule. Second, peroperative testing in lateral decubitus and under traction may not be possible. Third, if enough energy is applied, all types of instability can be reproduced and rendered "engaging". Fourth, a post-hoc peroperative diagnosis may be hard to incorporate in the surgical treatment plan. Therefore, an alternative approach was presented by Yamamoto et al. (2007). The authors mapped the path of the glenoid articular surface on the humeral head during abduction and external rotation. They proposed that if the Hill-Sachs lesion was contained within the contact zone of the humeral head with the glenoid, which averages $85 \%$ of the glenoid width as measured from the cuff footprint, the humeral head would offer enough bony support to stabilize the glenohumeral joint. This is a so-called "on-track" lesion (=non-engaging). If on the other hand, the lesion is wider or more medial than the glenoid track, the Hill-Sachs lesion will "engage" the glenoid rim and cause instability ("off-track" lesion). Moreover, because of concomitant anterior glenoid bone loss, the glenoid track can be diminished and a previously stable ontrack Hill-Sachs lesion may become unstable (off-track) in the presence of a glenoid rim defect (Di Giacomo et al., 2016).

\section{Material, methods and results TREATMENT Glenoid}

Failure of soft-tissue procedures in the presence of significant gleno-humeral bone loss is well documented (Burkhart and De Beer, 2000; Boileau et al., 2006). Historically, glenoid bone block procedures were introduced in order to "block" anterior translation of the humeral head over the glenoid rim. Eden and Hybinette described placing autologous tibial or iliac crest bone grafts as a mechanical barrier on the anterior glenoid rim. These procedures fell out of favour due to high incidences of postoperative degenerative arthritis. Although it is impossible to verify the historic data, it is generally believed that these degenerative changes were either the result of the chronic recurrent instability before the stabilization procedure or due to an excessive lateral graft positioning leading to graft-humeral head hyperpressure, posterior subluxation and rapid chondrolysis. An alternative technique, described by Latarjet, involved transplantation of the coracoid graft to the anterior glenoid neck. This variation theoretically improved stability by the additional stabilizing effect of the conjoint sling and the coraco-acromial ligament anterior reinforcement. Long-term clinical results have shown a dramatic reduction in recurrences after Latarjet-type 
procedures compared to the standard capsulolabral repairs (Young et al., 1998). Conversely, complications rates have significantly increased after the popularization of the coracoid transfer procedures. Such complications are mostly benign and treatable, yet can be devastating in cases of hardware or graft malpositioning and neurovascular injuries (Griesser et al., 2013). As an alternative, less invasive and hardware-free techniques have been devised, such as an arthroscopic version of the Latarjet procedure with good clinical outcomes (Lafosse and Boyle, 2010). More recently, further improvements have been suggested by replacing the screws with suture-based fixation methods in order to minimize hardware related issues (Boileau et al., 2016). Nevertheless, the complexity of the procedure and the steep learning curve have prohibited widespread acceptance of this technique. Resch et al. published promising results of the J-bone procedure. This procedure relies on the impaction grafting of a J-shaped iliac crest autograft after creation an anterior glenoid wedge osteotomy. The advantages are the absence of hardware and the option of performing the procedure arthroscopically (Anderl et al., 2016). North-American authors have published extensively on the use of fresh donor osteochondral allografts. These grafts offer the advantage of a cartilage surface, matching radii of curvature and absence of donor-site comorbidity. Availability, cost and risk of disease transmission have to be considered when using fresh frozen allografts (Provencher et al., 2009).

\section{Humeral Head}

Symptomatic humeral defects can be treated by bony augmentation of the humeral head using autograft, allograft or metallic implants (Armitage et al., 2010). The evidence concerning these procedures is scarce, yet biomechanical data has indicated that significant restoration of stability is feasible using bony humeral reconstruction (Giles et al., 2012). Alternatively, bone can be added to the anterior glenoid with the aim of widening the glenoid track, and thereby reducing the risk of "engagement". Although biomechanically feasible, bone grafting which exceeds the native glenoid surface area has shown high rates of resorption in clinical series (Di Giacomo et al., 2011). Therefore, we believe that adding an anterior glenoid bone graft in the absence of glenoid bone loss in order to stabilize a large Hill-Sachs lesion is relatively contra-indicated. An alternative is the so-called "remplissage" procedure. As the name suggests (from the French "to fill"), the aim of the procedure is to fill the defect with rotator cuff tissue. This converts the lesion to an extra-articular lesion and acts as a checkrein for anterior translation. Clinical studies have shown good outcomes using this technique in small to moderate sized Hill-Sachs lesions, yet the risk of loss of range of motion is present (Armitage et al., 2010). Humeroplasty, rotational humeral osteotomy and total shoulder replacement have been described for the treatment of large Hill-Sachs lesions but are rarely indicated.

\section{DECISION MAKING}

The therapeutic decision tree for shoulder instability in the presence of glenoid and humeral bone loss is multifactorial. Age, sex, sportive ambitions, hyperlaxity, and anatomical lesions need to be considered. Glenoid bone defects of $20-25 \%$ are traditionally considered the threshold for reconstructive anterior glenoid bone grafting procedures. However, the advent of the glenoid track concept has extended the applicability of glenoid bone augmentation procedures to cases with less pronounced glenoid bone loss (10-20\%) when combined with an offtrack Hill-Sachs lesions and in selected cases with an increased risk of recurrence such as young age, male sex, failed previous soft-tissue procedures, competitive athletic activity, and hyperlaxity. The correct indication for isolated humeral, isolated glenoid or combined surgical procedures is unknown. 
Similarly, the role of anatomic reconstructions such as the Eden-Hybinette, J-bone and allograft reconstructions in relation to the classic non-anatomical Latarjet procedures has not yet been defined. Traditional soft-tissue capsulo-labral repair should be reserved for low-risk patients with minimal bone loss, while non-operative treatment should be considered in the sedentary population.

\section{ASSOCIATED INJURIES \\ Cuff Tears}

The rotator cuff plays an important role in stabilizing the shoulder joint at both the mid-range of motion, through the concavity-compression mechanism, and at the endrange of motion by muscle action limiting the range and thereby protecting capsulolabral structures. Rotator cuff structures may be injured due to dislocation, and dislocation may be facilitated by the presence of rotator injuries (Figure 4). Rotator cuff tears are present in $7-32 \%$ of dislocations and the incidence increases with age (Berbig et al., 1999; Simank et al., 2006). This is believed to be due to pre-existent thinning and weakness of the rotator cuff in the older population and repetitive micro-injury in the throwing athlete. The surgeon should be suspicious of such injuries in cases with persistent pain and dysfunction 2 to 3 weeks after dislocation. The clinical findings are often attributed to nerve palsy, but may result from underlying cuff pathology. Not infrequently, both arise together, constituting a "terrible triad" of the shoulder (Pevny et al., 1998; Porcellini, 2012). Further investigation by advanced imaging techniques should be ordered in these circumstances to define the type and extent of rotator cuff injury.

\section{Treatment}

The presence of a rotator cuff lesion should be considered in conjunction with the traditional factors of decision making in shoulder instability such as enumerated above; patient age, functional demands, recurrence, hyperlaxity and bony defects. Literature has amply shown the importance of surgically addressing the rotator cuff lesions. Lahteenmaki et al. (2006) showed better outcomes after early surgical repair compared to conservative or delayed surgical treatment. A combination of anterior capsulolabral repair and rotator cuff repair is indicated in patients younger than 40-60 years (Hawkins et al., 1999; Porcellini et al., 2012), whereas in older patients, depending on functional demands, solitary cuff repair may be sufficient to stabilize the shoulder. The habitual postoperative capsulitis and resulting stiffness in older patients after arthroscopic or open shoulder surgery, has a protective effect in the cases of instability, and specific anterior capsulolabral repair is rarely required in this population.

\section{NERVE INJURY}

Neurologic structures can be injured as a result of anterior shoulder instability. De Laat et al. (1993) recorded an overall $13.8 \%$ incidence of EMG abnormalities in patients with persistent pain and loss of function after primary shoulder dislocation. The axillary nerve was most frequently injured, followed by the suprascapular nerve and radial nerve in a mixed population of instability and proximal humeral fractures. Isolated axillary nerve injuries frequently result from closed traction mechanisms. The nerve is thethered proximally by the infraclavicular plexus and distally by the terminal deltoid branches and stretched over the humeral head during glenohumeral dislocation. Patients older than 65 and patients presenting with an associated cuff lesion of greater tuberosity fracture have a higher risk of incurring a concomitant nerve lesion.

\section{Treatment}

Spontaneous recovery of axillary is expected in $85-100 \%$ of cases after closed shoulder trauma (Gumina et al., 1997; Atef et al., 2016). Patients are generally observed clinically and neurophysiologically for 3-6 months. If signs 


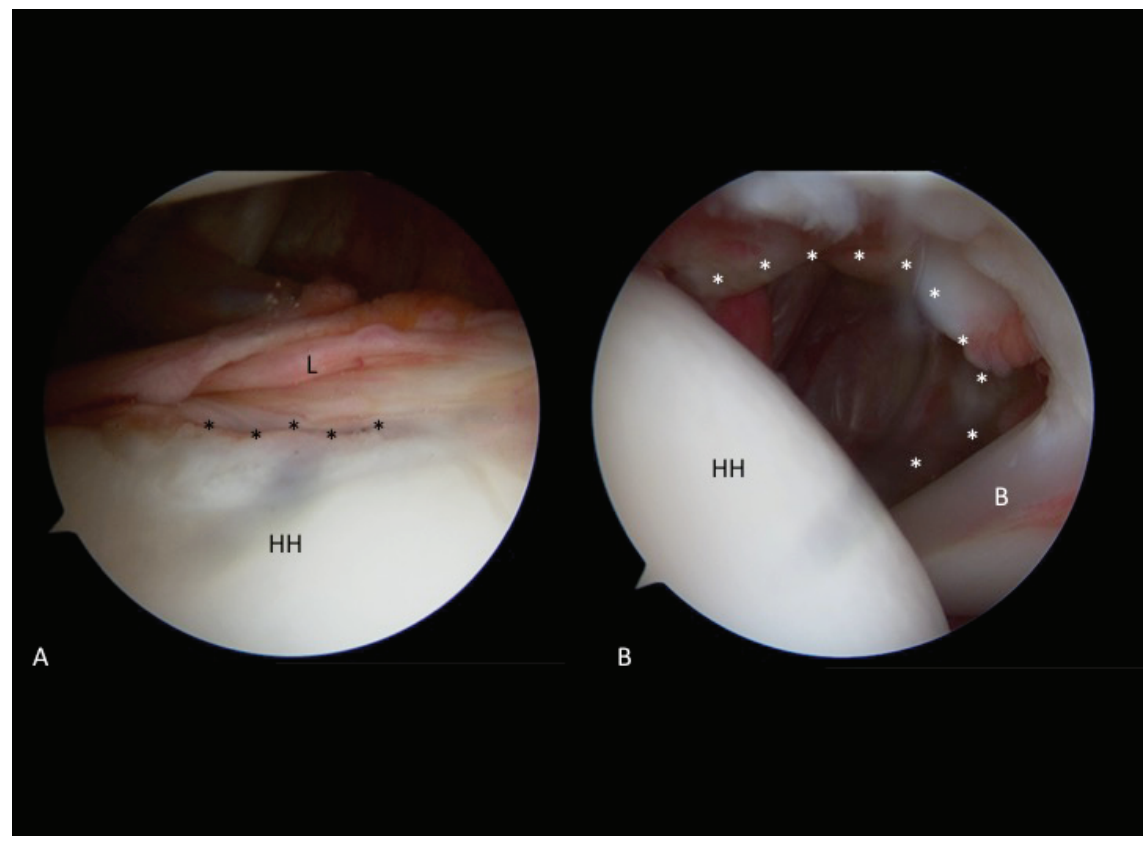

Figure 4. A. Anterior Bankart lesion in a left shoulder in lateral decubitus as seen from posterior. B. Important supraspinatus tear seen in the same patient after dislocation.G = Glenoid, $\mathrm{HH}=$ Humeral head, black asterisks indicate Bankart lesion, white asterisks indicate rotator cuff tear.

of recovery are not seen during this period, surgical intervention is advised before loss of motor end-plate function develops. Early distinction between neurapractic-axonotmetic and neurotmetic lesions is useful in predicting which patients will benefit from surgical intervention. Spontaneous recovery is expected in the former, but not the latter group. A new approach to nerve lesion diagnostics, combining electrodiagnostics and ultrasound imaging, termed " $3 \mathrm{D}$ assessment", is currently under development. The combined exam increases the sensitivity and specificity of early detection for lesions requiring operative treatment (Galvin et al., 2016; Terzis et al., 2010). If a lesion is found within a continuous nerve, serial clinical examinations and neurophysiologic testing can be ordered every 6-8 weeks until 3-6 months after injury. If a discontinuity or structural cause of nerve injury is seen, surgical exploration and intraoperative assessment is indicated. Surgical outcomes or surgical interventions have been shown to decline when lead-time exceeds 12-18 months from the injury. In these cases, procedures which do not rely on functional deltoid muscle motor end-plates such as tendon transfers, and salvage procedures such as glenohumeral arthrodesis are indicated

\section{REVISION SURGERY IN ANTERIOR SHOUL- DER INSTABILITY}

Trauma, misdiagnosis, and technical errors are the major causes of surgical failure regardless of the index procedure. Overall, the best results are obtained in revision cases after renewed high-energy trauma, after only one prior attempt at stabilization, and in the absence of a voluntary component to the instability (Boone et al., 2010). Fundamental to successful revision surgery is selecting the correct procedure. Typically, the surgeon's choice will be either a soft-tissue based repair or a bony procedure.

\section{REVISION SOFT TISSUE REPAIR}

Although some still consider open Bankart repair to be the gold standard procedure in cases of recurrence, several studies support the equivalence of arthroscopic revision for the appropriate indications (Arce et al., 
2012). However, revision capsulolabral repair should only be used in patients with minimal risk factors for recurrence, and must not be used in the presence of significant glenoid or humeral bone loss. Essential to the repair is the recreation of an anteroinferior labral bumper. Attachment of the plicated capsule to the glenoid face may serve to replicate a labral bumper in cases of labral deficiency. A rotator interval closure can be considered in cases of persistent laxity after these traditional repairs (Boileau et al., 2009).

\section{BONY PROCEDURES}

The coracoid transfer procedures possess numerous advantages in a revision setting and will be the only option left in many cases. The stabilizing effect of the transfer is multifactorial and obviates the need for a robust labral or capsular repair that is often difficult to achieve with a revision Bankart repair. The grafted coracoid process restores the glenoid articular surface and normalizes the glenohumeral contact pressure (Ghodadra et al., 2010). Hill-Sachs engagement is avoided by widening of the glenoid track and the transferred conjoint tendon provides dynamic stability in the main position of apprehension (Wellmann et al., 2011). The postoperative rehabilitation can be accelerated with no limitations on external rotation due to the rigid fixation of the bone graft to the glenoid neck.

In revision cases of failed coracoid transfer procedures, glenoid bone loss may need to be addressed by structural bone grafting, such as in the Eden-Hybinette technique of autogenous tricortical iliac crest bone grafting (Lunn et al. 2008). The use of distal tibial allografts or even glenoid allografts have also been suggested because of the anatomic similarity to the glenoid articular surface, osteochondral nature of the graft, and capacity for secure fixation and incorporation (Provencher et al. 2009).

Most Hill-Sachs lesions can be rendered inconsequential with an adequate anterior repair and capsular plication. In large lesions that threaten stability, engagement may be eliminated with restoration of the articular arc through coracoid transfer or bone grafting as mentioned earlier. Some investigators have recommended filling the defect with an osteochondral allograft to correct the humeral head deformity (Chapovsky et al., 2001). The defect may also be filled with the posterior capsule and the adjacent infraspinatus tendon ("Remplissage procedure") to prevent engagement and limit anterior translation of the humeral head, yet the indications and long-term outcomes of these procedures are not well understood, and their role in revision surgery has not yet been delineated.

\section{Discussion and conclusions}

Specific attention is warranted in cases of traumatic anterior shoulder instability complicated by cartilage injury, glenoid and/or humeral bone defects, rotator cuff injuries, nerve lesions or previous stabilizing surgery. Patients with prolonged pain and dysfunction after an instability event require further investigation. Especially older patients are at risk of associated injuries, but presentation in younger patients is possible and should not be missed. Full clinical and imaging work-up is necessary before decision-making in these complex cases. Clear guidelines are lacking in the literature due to the relative scarcity of the problem. A careful analysis of patient risk factors, anatomical lesions and functional demands is mandatory before proceeding with any therapeutic plans. 


\section{REFERENCES}

Anderl, W., Pauzenberger, L., Laky B., Kriegleder, B., Heuberer P.R. (2016). 'Arthroscopic Implant-Free Bone Grafting for Shoulder Instability with Glenoid Bone Loss: Clinical and Radiological Outcome at a Minimum 2-Year Follow-Up.'The American Journal of Sports Medicine, 44 (5): pp. 1137-1145. Arce, Guillermo, Francisco Arcuri, Diego Ferro, and Enrique Pereira. (2012) 'Is Selective Arthroscopic Revision Beneficial for Treating Recurrent Anterior Shoulder Instability?.' Clinical Orthopaedics and Related Research 470 (4): 965-971.

Armitage, M.S., Faber K.J., Drosdowech D.S., Litchfield R.B., Athwal G.S. (2010) 'Humeral Head Bone Defects: Remplissage, Allograft, and Arthroplasty.' Orthopedic Clinics of NA 41 (3): 417-25.

Ashraf A., El-Tantawy A., Gad H., Hefeda M. (2016) 'Prevalence of Associated Injuries After Anterior Shoulder Dislocation: a Prospective Study.' International Orthopaedics 40 (3): 519-24.

Baudi P., Campochiaro G., Rebuzzi M., Matino G., Catani F. (2013) 'Assessment of Bone Defects in Anterior Shoulder Instability.' Joints 1 (1): 40-48.

Berbig R., Weishaupt D., Prim J., Shahin O. (1999) 'Primary Anterior Shoulder Dislocation and Rotator Cuff Tears.' Journal of Shoulder and Elbow Surgery/American Shoulder and Elbow Surgeons ... [Et Al] 8 (3): 220-25. Boileau, P., Richou J., Lisai A., Chuinard C., Bicknell R.T. (2009) 'The Role of Arthroscopy in Revision of Failed Open Anterior Stabilization of the Shoulder.' Arthroscopy 25 (10): 1075-84.

Boileau P., Villalba M., Jean-Yves H., Balg F., Ahrens P., Neyton L. (2006) 'Risk Factors for Recurrence of Shoulder Instability After Arthroscopic Bankart Repair.' The Journal of Bone and Joint Surgery (American) 88 (8): 1755-63.

Boileau, P., Gendre P., Baba M., Thelu C.E. Baring T., Gonzalez J.F., Trojani C. (2016) 'A Guided Surgical Approach and Novel Fixation Method for Arthroscopic Latarjet.'
Journal of Shoulder and Elbow Surgery 25 (1): 78-89.

Boone J.L, Arciero R.A. (2010) 'Management of Failed Instability Surgery: How to Get It Right the Next Time.' Orthopedic Clinics of NA 41 (3): 367-79.

Burkhart, Stephen S, and Joe F De Beer. (2000) 'Traumatic Glenohumeral Bone Defects and Their Relationship to Failure of Arthroscopic Bankart Repairs.' Arthroscopy 16 (7): 677-94.

Chapovsky F., Kelly J.D. 4th. (2005) 'Osteochondral Allograft Transplantation for Treatment of Glenohumeral Instability.'Yjars 21 (8): 1007.

de Laat E.A., Visser C.P., Coene L.N., Pahlplatz P.V., Tavy D.L. (1994) 'Nerve Lesions in Primary Shoulder Dislocations and Humeral Neck Fractures. a Prospective Clinical and EMG Study.' The Journal of Bone and Joint Surgery. British Volume 76 (3): 381-83.

Denard P., Dai X., Burkhart S.S. (2015). 'Increasing Preoperative Dislocations and Total Time of Dislocation Affect Surgical Management of Anterior Shoulder Instability.' International Journal of Shoulder Surgery 9 (1). India: Medknow Publications \& Media Pvt Ltd: 1-5.

DePalma A.A., and Gruson K.I. (2012) 'Management of Cartilage Defects in the Shoulder.' Current Reviews in Musculoskeletal Medicine 5 (3). New York: Current Science Inc.: 254-62.

Di Giacomo G., Costantini A., de Gasperis N., De Vita A., Lin B.K.H, Francone M., Beccaglia M.A.R., Mastantuono M. (2011) 'Coracoid Graft Osteolysis After the Latarjet Procedure for Anteroinferior Shoulder Instability: a Computed Tomography Scan Study of Twenty-Six Patients.'Journal of Shoulder and Elbow Surgery 20 (6): 989-95.

Di Giacomo G., de Gasperis N., Scarso P. (2016) 'Bipolar Bone Defect in the Shoulder Anterior Dislocation.' Knee Surgery, Sports Traumatology, Arthroscopy 24 (2): 479-88. 
Galvin J.W., Eichinger J.K. (2016). 'Outcomes Following Closed Axillary Nerve Injury: a Case Report and Review of the Literature.' Military Medicine 181 (3): e291-97.

Ghodadra N., Gupta A., Romeo A.A., Bach B.R., Verma N., Shewman E., Goldstein J. Provencher M.T. (2010) 'Normalization of Glenohumeral Articular Contact Pressures After Latarjet or Iliac Crest Bone-Grafting.' The Journal of Bone and Joint Surgery (American) 92 (6): 1478-89. 20.

Giles J.W., Elkinson I., Ferreira L.M., Faber K.J., Boons H., Litchfield R., Johnson J.A., Athwal G.S. (2012) 'Moderate to Large Engaging Hill-Sachs Defects: an in Vitro Biomechanical Comparison of the Remplissage Procedure, Allograft Humeral Head Reconstruction, and Partial Resurfacing Arthroplasty.' Journal of Shoulder and Elbow Surgery/American Shoulder and Elbow Surgeons ... [Et Al] 21 (9): 1142-51.

Griesser M.J., Joshua H.D., Hussain W.M., Jones M.H., Bishop J.Y., Miniaci A. (2013) 'Complications and Re-Operations After Bristow-Latarjet Shoulder Stabilization: a Systematic Review.' Journal of Shoulder and Elbow Surgery/American Shoulder and Elbow Surgeons... [Et Al.] 22 (2). Elsevier Ltd: 286-92. Griffith, J.F., Antonio G.E., Yung P.S.H., Wong E.M.C., Yu A.B., Ahuja A.T., Ming Chan K. (2008) 'Prevalence, Pattern, and Spectrum of Glenoid Bone Loss in Anterior Shoulder Dislocation: CT Analysis of 218 Patients.'AJR. American Journal of Roentgenology 190 (5): 1247-54.

Bertino G.S.A., Di Giorgio G., Postacchini F. (2005) 'Injury of the Axillary Nerve Subsequent to Recurrence of Shoulder Dislocation. Clinical and Electromyographic Study.' La Chirurgia Degli Organi Di Movimento 90 (2): 153-58.

Hawkins R.J., Morin W.D., Bonutti P.M. (1999) 'Surgical Treatment of Full-Thickness Rotator Cuff Tears in Patients 40 Years of Age or Younger.' Journal of Shoulder and Elbow Surgery/American Shoulder and Elbow Surgeons ... [Et Al] 8 (3): 259-65.

Hovelius L., Modolv S. (2009) 'Neer Award 2008: Arthropathy After Primary Anterior
Shoulder Dislocation.' Journal of Shoulder and Elbow Surgery/American Shoulder and Elbow Surgeons ... [Et Al] 18 (3). Elsevier Ltd: 339-47.

Itoi E., Nobuyuki Y., Kurokawa D., Sano H. (2013) 'Bone Loss in Anterior Instability.' Current Reviews in Musculoskeletal Medicine 6 (1): 88-94.

Kaar S.G., Fening S.D., Jones M.H., Colbrunn R.W., and Miniaci A. (2010) 'Effect of Humeral Head Defect Size on Glenohumeral Stability: a Cadaveric Study of Simulated Hill-Sachs Defects.' The American Journal of Sports Medicine 38 (3): 594-99.

Lafosse L., Boyle S. (2010) 'Arthroscopic Latarjet Procedure.' Journal of Shoulder and Elbow Surgery 19 (2 Suppl): 2-12.

Lahteenmaki H.E., Virolainen P., Hiltunen A., Heikkila J., Nelimarkka O.I. (2006) 'Results of Early Operative Treatment of Rotator Cuff Tears with Acute Symptoms.' Journal of Shoulder and Elbow Surgery/American Shoulder and Elbow Surgeons...[Et Al] 15 (2): 148-53.

Lunn J.V., Castellano-Rosa J., Walch G. (2008) 'Recurrent Anterior Dislocation After the Latarjet Procedure: Outcome After Revision Using a Modified Eden-Hybinette Operation.' Journal of Shoulder and Elbow Surgery/ American Shoulder and Elbow Surgeons ... [Et Al] 17 (5): 744-50.

Neviaser T.J. (1993) 'The GLAD Lesion: Another Cause of Anterior Shoulder Pain.' Yjars 9 (1): 22-23.

Page, R.S. (2008) 'Managing Chondral Lesions of the Glenohumeral Joint.'International Journal of Shoulder Surgery 2 (4). India: Medknow Publications: 77-78.

Pevny T., Hunter R.E., Freeman J.R. (1998) 'Primary Traumatic Anterior Shoulder Dislocation in Patients 40 Years of Age and Older.' Yjars 14 (3): 289-94.

Porcellini G., Caranzano F., Campi F., Paladini P. (2012) 'Instability and Rotator Cuff Tear.' Medicine and Sport Science 57: 41-52. Provencher M.T., Ghodadra N., LeClere L., Solomon D.J., Romeo A.A. (2009) 'Anatomic Osteochondral Glenoid Reconstruction for 
Recurrent Glenohumeral Instability with Glenoid Deficiency Using a Distal Tibia Allograft.' Arthroscopy 25 (4): 446-52.

Shaha J. S., Cook J.B., Song D.J., Rowles D.J., Bottoni C.R., Shaha S.H., Tokish J.M. (2015) 'Redefining "Critical" Bone Loss in Shoulder Instability: Functional Outcomes Worsen with 'Subcritical' Bone Loss.' The American Journal of Sports Medicine 43 (7): 1719-25.

Simank H.G., Dauer G., Schneider S., Loew M. (2006) 'Incidence of Rotator Cuff Tears in Shoulder Dislocations and Results of Therapy in Older Patients.' Archives of Orthopaedic and Trauma Surgery 126 (4): 235-40.

Taylor D.C., Arciero R.A. (1997) 'Pathologic Changes Associated with Shoulder Dislocations. Arthroscopic and Physical Examination Findings in First-Time, Traumatic Anterior Dislocations.' The American Journal of Sports Medicine 25 (3): 306-11.

Terzis J.K., Barmpitsioti A. (2010). 'Axillary Nerve Reconstruction in 176 Posttraumatic Plexopathy Patients.' Plastic and Reconstructive Surgery 125 (1): 233-47.

Wellmann M,H., Smith F.T., Petersen W., Siebert C.H., Agneskirchner J.D., Hurschler C. (2011) 'Biomechanical Investigation of the Stabilization Principle of the Latarjet Procedure.' Archives of Orthopaedic and Trauma Surgery 132 (3): 377-86.

Widjaja A.B., Tran A., Bailey M., Proper S. (2006) 'Correlation Between Bankart and Hill-Sachs Lesions in Anterior Shoulder Dislocation.' ANZ Journal of Surgery 76 (6): 436-38. Yamamoto N., Itoi E., Abe H., Minagawa H., Seki N., Shimada Y., Okada K. (2007) 'Contact Between the Glenoid and the Humeral Head in Abduction, External Rotation, and Horizontal Extension: a New Concept of Glenoid Track.' J Shouder Elbow Surg., 16 (5): 649-56.

Young A., Goutallier D., Glorion C. (1998) 'Long-Term Results of the Latarjet Procedure for the Treatment of Anterior Instability of the Shoulder.' The Journal of Bone \& Joint Surgery 80 (6): 841-52. 
Authors reported no source of funding. Authors declared no conflict of interest.

Author responsible for correspondence: Olivier Verborgt

Department of Orthopaedic Surgery and Traumatology, AZ Monica, Antwerp, Belgium Stevenslei 202100 Antwerp - Belgium olivier.verborgt@azmonica.be olivier.verborgt@icloud.com
Autorzy nie zgłosili źródła finansowania.

Autorzy nie deklarowali konfliktu interesów.

Autor odpowiedzialny za korespondencję: Olivier Verborgt

Department of Orthopaedic Surgery and Traumatology, AZ Monica, Antwerp, Belgia Stevenslei 202100 Antwerp - Belgium olivier.verborgt@azmonica.be olivier.verborgt@icloud.com 